\title{
The Organizational Life: Daily Surveillance and Daily Resistance in North Korea
}

\author{
Andrei Nikolaevich Lankov, In-ok Kwak, \\ and Choong-Bin Cho
}

\begin{abstract}
The "organizational life" is an important part of the daily existence of North Koreans. Every adult in North Korea has to be a participant in a multitude of rituals that serve a dual purpose of surveillance and indoctrination. In this article, we describe how the organizational life is arranged and also explain the ways it contributes to maintaining the domestic stability of North Korea and to manufacturing consent for the current regime. The study is based largely on refugee interviews. KEYWORDS: North Korea, surveillance, ideology, indoctrination, Korean Workers Party, horizontal propaganda, coproduction, ideological mobilization, refugees
\end{abstract}

DESPITE THE EMERGENCE OF NEW ARCHIVAL DATA, SURVEILLANCE AND indoctrination in communist states remain somewhat understudied topics. One cannot help but agree with Zdenek Konopásek and Zuzana Kusá, who note that "the reality of European communist regimes has been practically absent in these contemporary discourses on power. ... Perhaps the power of communists looks too specific; too rough and coercive as well as too centered in the hands of the few; too mechanical, openly oppressive and violent; too simply located. . . . Also, the communist power would hardly draw attention from those for whom the study of power is a part of the critique of Western capitalism" (Konopásek and Kusá 2006, 343).

However, by no means does the power of communist regimes come through violence (or the threat thereof) alone. Sheila Fitzpatrick and other supporters of the "revisionist school" in the Soviet studies of the 1980s emphasized that the Soviet system would be unsustainable without a significant measure of consent or, at least, acquiescence from below. The same applies to the North Korean system, which has survived seemingly impossible odds. This support, however, has to be 
maintained and generated. In the study that follows, we examine an institution (or rather a set of interconnected institutions and practices) that plays a major role in both manufacturing consent, to borrow a wellknown expression by Noam Chomsky, and supervising the population.

More specifically, we deal here with a peculiar North Korean institution known as chochik saenghwal (organizational life, or OL). It is obvious for any student of state socialist systems that the North Korean OL owes much to Soviet and, more broadly, Leninist influences. Nonetheless, it does not have a clear analogue: the $\mathrm{OL}$ as it emerged in North Korea in the 1960s has a number of unique features not to be found in other communist countries.

Generally speaking, OL is a standard reference to a highly formalized array of surveillance and indoctrination practices that are conducted within a set of networks, each run by a particular government-controlled "organization" (chochik). There are five such organizations, and every adult North Korean, depending on age, place of employment, and other variables, belongs to one (and only one) of them. Each of these organizations arranges regular-and very frequent-indoctrination meetings, mutual and self-criticism sessions, and other activities whose structure and social role are the major focus of this article.

The OL serves dual purposes of surveillance and indoctrination. Unlike most propaganda or surveillance systems, it has an explicit goal of reaching every member of society and making each person into an active coparticipant in the surveillance and indoctrination processes. Within the OL system, the surveillance and indoctrination are interconnected, but can still—and for analytical purposes should—be separated.

The OL has been studied only briefly in the existing literature on North Korea, which is not surprising given that this literature tends to concentrate on elite politics. In English publications, the OL is described at some length by Helen-Louise Hunter (1999, 60-65) and Sung Chull Kim (2006, 65-75). However, these descriptions are still relatively short and do not treat the OL in a systematic way; and, of course, they had much less information at their disposal (a dramatic increase in refugee numbers has provided us with a wealth of data).

Our article consists of three parts. The first part deals with the organizations' recruitment/membership, although the word "recruitment" is somewhat misleading since membership in most of the organizations is compulsory. The second part examines indoctrination activities and peculiarities of the North Korean attitude toward indoctrination, with an emphasis on mutual indoctrination and what Philip Roeder (1989) described as "coproduction" (political activities related to implementation 
of the authorities' decisions). The third part concentrates on the role played by the OL system in surveillance and monitoring of daily North Koreans' daily life. It shows that the unusual totality of the system, combined with the obligatory participation of virtually the entire adult population, contributes much toward the manufacturing of consent for the regime.

We concentrate in this article on the grassroots level; our task is to trace how OL activities are experienced by the average North Korean. We do not pay special attention to the content of the messages that are delivered to the North Koreans through the OL. Rather, our major area of interest is how these messages are delivered.

The all-encompassing nature of this OL implies that virtually every North Korean has a good understanding of how the OL grassroots activities are supposed to be performed - and also how they are actually performed. We therefore conducted open-ended interviews with seven North Korean refugees in Seoul, most of whom prior to their defection were minor functionaries in the OL system (five of them were cell secretaries in one organization or another). Reports from Rodong sinmun (the official newspaper of the Central Committee of the Workers' Party of Korea) and the Korean Central News Agency are also used whenever appropriate; the official publications are remarkably reluctant to discuss the OL but still provided some important information.

\section{The Party and Its "Transmission Belts": Nobody Left Outside}

As noted earlier, the OL activities are all conducted within a set of networks, each run by a particular "organization." Five such centralized nationwide networks coexist in North Korea: those of the Korean Workers' Party (KWP), the Youth Union, the Trade Union, the Farmers' Union, and the Women's Union (one could also add the Children's Union to this list, but it is not usually considered an organization in its own right). In the official parlance, the organizations (kunlo taechung chochik) are described by their full name as organizations of the working masses.

Every North Korean must belong to one-and only one-of these organizations. This approach prevents ambiguity and makes control more efficient. With the important exception of the KWP, membership in a particular organization is compulsory and bestowed automatically, exact affiliation being defined by age, gender, place of employment, and other variables. People are not recruited to the Trade Union or Women's Union; rather their OL affiliations are switched automatically according 
to a clearly defined and universally known set of rules that assign every North Korean to a particular category.

The most important of all five organizations is the KWP, the local incarnation of the Communist Party, and the sole political party of the country (two other North Korean parties exist only on paper). Functions of a ruling Leninist party are numerous, but for the purposes of the present study we concentrate exclusively on the role the KWP plays in the OL.

In theory, every North Korean above the age of eighteen is eligible to join the KWP. ${ }^{1}$ The formal admission procedure is similar to what the Communist Party of the Soviet Union once required: an applicant, upon presentation of recommendations from two party members and a (rather formal and ritualized) discussion at a party meeting, obtains approval from a higher-level committee. After that, the normal practice is that he or she becomes first a candidate member and then, usually within six to twelve months, a full KWP member (exceptions are possible but rare). ${ }^{2}$

As in other communist states, KWP membership is highly competitive. In this regard, the KWP is different from other North Korean organizations where membership for a particular category is obligatory and bestowed automatically. The KWP committees are issued quotas that determine how many new members can be admitted to the party in any given year, so actual selection is usually done by the party secretary and influential cadres. Theoretically, the right to join the KWP is reserved for exemplary workers, but, according to interviewees (B-05, B06; see Table 1), bribing party officials for the right to be admitted to the party has long become a common occurrence.

In their interviews and writings, North Korean refugees frequently mention easy access to party membership as an important perk associated with a particular job. For example, refugees are virtually unanimous when they report that the major attraction of long and demanding

Table 1 List of Interviewees (interviews conducted in 2009 and 2011)

\begin{tabular}{lccl}
\hline Interviewee & Age & Sex & Position \\
\hline B-01 & 46 & M & \\
B-02 & 70 & M & \\
B-03 & 42 & F & Cell secretary, Women's Union \\
B-04 & 30 & F & Cell secretary, Youth Union \\
B-05 & 54 & M & Cell secretary, KWP \\
B-06 & 41 & M & Factory branch, party secretary, KWP \\
B-07 & 46 & M & Factory branch, deputy party secretary, KWP \\
\hline
\end{tabular}


military service is the opportunity to join the KWP (Pak 2007; Ch'oe 2005; B-01, B-06).

The KWP membership is large. In 1980, the last time relevant statistics were officially released, KWP membership was stated to be 3 million, a figure that has probably increased since then. Even the 1980 figure still amounts to at least 12 percent of the entire population. This is well above, say, the comparative ratio in the USSR in the 1980s, where Communist Party members constituted a mere 6.8 percent of the population (Shoemaker 1990, 60). In Poland, in 1980, the percentage was 8.3, and in Hungary it was 7.6. Interestingly, of all European countries, a similarly high ratio could be found only in Romania, a country that in other regards also demonstrated many similarities with North Korea: in Romania in the late 1980s, 15.8 percent of the population held membership in the Romanian Communist Party (Stoica 2005, 687).

With such a high percentage of party members it is impossible to equate the party rank and file with the "elite." In North Korea, party membership is much coveted not because it gives immediate access to privilege, but because it is a necessary (but by no means sufficient) prerequisite for winning virtually any prestigious job. According to one interviewee (B-06), "In order to marry well, to become an official, or to get a promotion, North Korean males must become members of the KWP." Another (B-07) stated that "in North Korean society, there is no way up for somebody who is not a party member. Such a person cannot transfer to a good job and cannot attain a good place in society."

In other words, KWP membership is not a privilege in itself, but a necessary first step on the way to a political and administrative career where eventual rewards might be considerable. As Andrew Walder $(1995,309)$ noted, "The power to offer career opportunities has long been recognized as a central pillar of communist rule, either as a system of social control (rewards for loyalty) or as a means of fostering socialization and (at least outward) ideological conformity."

This attractiveness is further reinforced by some peculiarities of the North Korean society. Until the recent emergence of semiofficial markets, the North Korea elite was a near-perfect embodiment of what George Konrád and Ivan Szelenyi once described as "redistributive elite in a redistributive economy." In North Korea, the party-state's monopoly on productive activity is used to redistribute material goods in favor of the political elite (Konrád and Szelenyi 1979). In a society arranged along such lines, an administrative career also serves as the most common (if not the only) path to material affluence - a situation that makes administrative advancement even more attractive. In North Korea dur- 
ing the Kim Il Sung period (until 1994). this tendency was taken to an extreme: in a situation where money could not buy much (due to acute shortages and total rationing), officials were entitled to especially generous rations, which included items beyond the reach of common North Koreans. This was a major incentive that made people strive for party membership, and, once accepted into the party ranks, to conform to the expected standards of behavior. It is remarkable that the emergence of the grassroots market economy in the late 1990s had a noticeable negative impact on the efficiency of the OL system.

Inside the system of North Korea's five "organizations," the KWP is not a primus inter pares but holds a special guiding role as the major pillar of the Leninist society. The KWP Statute stipulates this most explicitly: "The Korean Workers' Party is the highest form of the revolutionary unit among all organizations of the working masses" (cited in Simons and White 1984, 265). This special role of the KWP is also enshrined in Article 11 of the North Korean constitution.

By joining the KWP, the upwardly mobile voluntarily "commit themselves to a greater degree of political scrutiny . . . in exchange for career advancement" (Walder 1995, 313). The reward, albeit delayed and available only for the most zealous and loyal, is the possibility of eventually entering the ruling elite. The other organizations are different: with the partial exception of the Youth Union, they do not normally serve as recruiting grounds for the future elite. They play a more moderate role, primarily being the institutions for universal daily indoctrination and monitoring. People do not really make careers in any of the organizations except the KWP: all mid- and high-level positions in other organizations belong to career party cadres, and no amount of activism would help a Trade Union or Women's Union member rise above the level of junior organizer. "People who want to become cadres, must join the party before they turn thirty or so. One cannot develop a significant career by working hard at the Women's Union" (B-03).

Stalin once famously described the outside-the-party mass organizations as Leninist Party "transmission belts," whose raison d'être is to transmit the party's will to the masses. ${ }^{4}$ The transmission belts metaphor was once frequently used in Soviet publications, but after de-Stalinization in the 1950s, it all but disappeared from the official parlance of Eastern Europe. In North Korea, Stalin's old expression remains alive and well, so to this day "organizations of the working masses" are routinely described as KWP-driven transmission belts (inchontae)—without any reference to the foreign origin of the simile, of course. ${ }^{5}$ This subordinate position of the other organizations is further emphasized by 
the fact that virtually all mid- and high-level full-time managerial posts in the various organizations are occupied by the cadres who are KWP members - the only case where simultaneous membership in two organizations is allowed.

As was the case in the USSR, China, and countries of Eastern Europe, a local version of the Party Youth is the second most important of the organizations in North Korea-the first among the transmission belts, so to speak. The Youth Union (Kim Il Song sahoechuui ch'ongnyon tongmaeng; Kimilsungist Socialist Youth Union) can be described as a "junior party" (for a detailed description of its structure, see Sejong Institute 2004, 15). North Korea's Youth Union was created as a North Korean copy of the Soviet Komsomol and still retains numerous features that were once borrowed from its Soviet prototype.

Youth Union membership is open to all young North Koreans between the ages of fourteen and thirty. Unlike the much coveted KWP membership, Youth Union membership is bestowed almost automatically. Technically, the applicants are required to pass an admissions procedure designed to be similar to that of the KWP, but applications are never rejected - at least none of our informants ever heard about such a rejection. Virtually all North Koreans are expected and indeed required to apply for Youth Union membership as soon as they turn fourteen.

Therefore, every North Korean between the ages of fourteen and thirty is, by default, a Youth Union member as far as OL duties are concerned. There are two exceptions to this rule, however. First, those who join the KWP before they reach the age of thirty switch their OL activities to the party organization (another reminder of the party's absolute hegemony in the OL system). Second, if a married woman becomes a full-time housewife, she is transferred to the Women's Union, even if she has not yet turned thirty by the time of marriage; this obviously reflects the emphasis on the traditional family role as a means of social control (B-03, B-05).

So, what happens to a North Korean once he or she is too old to be a member of the Youth Union but, at the same time, was not lucky enough to be accepted into the party ranks? With the same exception regarding KWP members, all industrial employees older than thirty by default belong to a Trade Union organization at their workplace (agriculture employees are members of the Farmers' Union which is very similar to the Trade Union).

Housewives' OL is handled by the Women's Union, whose membership includes all unemployed women (overwhelmingly full-time housewives) if they are not members of the KWP. 
There is no special outlet for unemployed men that can play a similar role to that of the Women's Union. Only health reasons are considered to be sufficient grounds for unemployment if one is a male, and handicapped males are not obviously deemed an important or large enough group. Seniors are another de facto exempted group. "Women remain in the Women's Union until they turn sixty-five. After that age, it is acceptable if they do not participate in the OL, even though they can if they wish" (B-03).

The real seat of power in each organization is its Central Committee or, rather, its bureaucracy. The Central Committee controls province-level, county-level, and city-level branches of the organizations, which in turn are run by their own committees (the KWP and Youth Union also have a completely separate hierarchy for the military forces). Below the county/city level, the organizations are largely arranged according to enterprises (also called "work units")—factories, shops, schools, and the like. Therefore, within each work unit there are normally coexisting networks of three organizations: the KWP, Youth Union, and Trade Union (the Farmers' Union takes the place of the Trade Union in agricultural work units).

Members of the organizations are required to pay monthly membership fees-up to 10 percent of their income, but usually much less. As recent research indicates, such fees were a major contribution to the budget of the Communist Party in Stalin's Russia (Belova and Lazarev 2007), but it remains to be seen to what extent the fees are financially important in North Korea. Irrespective of the fee's actual significance, North Korea's propaganda assigns them a great symbolic meaning: "If membership fees are not paid, it is a big deal!" (B-03). ${ }^{6}$ This symbolism might be the reason why the fees are not simply withheld from paychecks: presenting fees is a minor ritual that emphasizes membership and loyalty.

In all organizations, the cells are the major focus of the OL-where most regular OL activities are conducted. A KWP cell is required to have not less than five and not more than thirty members (the norm is ten to twenty-five members). Similar size restrictions exist in other organizations as well. These size limits facilitate personal interaction among cell members and also increase the efficiency of OL small-group activities.

At first sight, the overall structure of the North Korean organizations appears familiar to students of the Communist bloc. It is clearly an outsized, modified, and formalized version of what was once known in the USSR as obshestvennaia zhizn (social life). Even the Korean term 
for the OL itself is, in all probability, borrowed from the Chinese: in post-1949 Chinese political parlance, the term zuzhi shenghuo, written with the same ideograms as its Korean equivalent, chochik saenghwal, has been applied to describe the somewhat similar activities of the KWP and its "transmission belts" (Yang 1994, 269).

Nonetheless, in spite of similarities, North Korea's OL is in many ways different from its prototypes. One of the major and most striking differences is the all-inclusive nature of the organizations network in North Korea. In Stalin's Russia, as well as in other Leninist regimes that emulated it, the vigorous surveillance and indoctrination activities, analogous to the North Korean OL, were normally limited to the cells of a local Leninist party and, to a lesser extent, to the cells of the Party Youth (the latter was seen as a ground for training/monitoring future party cadres). A majority of the populace were left outside the reach of the organizations and were exempted from the vigorous indoctrination and monitoring regime that was reserved for the party members alone. In the Soviet Union, neither housewives nor farmers were required to attend the obligatory weekly indoctrination sessions, let alone be active participants of such exercises.

The principle of exclusive membership in one, and only one, organization is also unique to North Korea: in the Soviet Union a party member could simultaneously be a member of a trade union (and was such a member by default as long as he or she was employed in a state company). The same is applicable to members of komsomol, the Soviet equivalent and, indeed, prototype of North Korea's Youth Union. At one time, that was the case in North Korea as well. However, in 1974, a new policy stipulated that henceforth every North Korean would conduct his or her OL within a single organization (Yi and Hwang 2009, 138). Such exclusive membership helps to delineate the areas of responsibility of the different organizations, so it is clear which organization is responsible for which individual member of society at any given moment.

\section{Coproduction and "Horizontal Propaganda"}

The OL consists of two connected but different types of activities. Some activities (especially the mutual criticism sessions) are related to mutual monitoring, while others are best described as a mixture of indoctrination and activities that Philip Roeder (1989) has defined as "coproduction." In his studies of somewhat similar-albeit less totalizing-forms of pseudospontaneous political activities in the Soviet Union, Roeder applied this term to the operations of the Communist Party and its 
"transmission belts" in the Leninist regimes. Coproduction might appear superficially similar to political participation, but it differs from the participation in its relationship to the decisionmaking process: while political participation is an activity aimed at influencing decisionmaking at the government level, coproduction is implementation of decisions that have already been made. As Roeder noted, in the Leninist polities many forms of participatory activities-such as participation in the officially endorsed elections-actually mask involvement in coproduction (Roeder 1989, 861). The significant part of the North Korean OL can be described as a combination of coproduction and indoctrination.

Every week a cell of a North Korean organization stages three events: two indoctrination sessions and a mutual criticism session. There are two types of indoctrination sessions: kangyon (lectures) and haksup (political study sessions), which differ in some small regard. Lectures and study sessions are normally conducted by selected members of the same organization, but in some rare cases, professional indoctrinators might be invited as well (B-06, B-07). The participants are told about the current political situations, the greatness of Kim Jong Il and his family, the evil nature of the imperialist enemies, and other key topics of the official discourse.

The numerous materials, especially pronouncements and speeches of Kim Jong Il and Kim Il Sung, are supposed to be memorized; as in Mao's China, North Korean propagandists want their target audience to remember the sacral texts verbatim. Twice a year, all KWP members pass a written test, demonstrating their knowledge of the required "study questions." One of our interviewees (B-06) explained: "Usually during the test there are two questions on politics, two questions on economics, one question on culture, and one question on songs. ${ }^{7}$ For example [the question on politics may be something like]: 'What are the major points for building a powerful and prosperous state?' On economics they may ask, 'What are the major requirements for one to work efficiently?' For culture-related questions, they may ask about proper dress codes or hairstyles. As regards the songs, they usually ask to write down the lyrics of a particular song."

Another part of the OL is the chongki ch'onghwa (regular meeting), which is copied from similar meetings in the USSR. Historically, these meetings have their roots in the early days of the socialist/communist movement, before the emergence of Leninism, when the groups of the radical left were still democratic organizations and policy issues were discussed freely. However, the initial democratic meaning of these gatherings was lost many decades ago, and the meetings became a good example of Roeder's "coproduction masked as participatory activity." 
Indeed, all trappings of participatory politics are present and faithfully emulated: resolutions are voted on and committees are elected-even though the participants know perfectly well that they are supposed to unanimously vote for the predetermined candidates and decisions.

Interviewee B-02, once a party secretary himself, describes a typical "regular meeting": "At first, a poko (report) is presented, and then four to six cell members make speeches. Those members are preselected, and the party secretary helps them write their speeches. Then the party secretary proposes a resolution. In the report, the secretary will talk about the international and domestic situation and new instructions from the party and how the members of the party must behave in meeting new demands. For example, the secretary might talk about [the joint USKorean military exercises called] 'Team Spirit' and the increasing threat of imperialist aggression; then he might talk about the need to work even harder to protect the Republic against its enemies. He then might talk about recent achievements and, finally, about the problems and failures of our work unit and its members, as well as about the reasons for its failures. The participants in the discussion will then deliver short speeches, promising to work harder and be ever ready to fight the enemy."

In the OL, coproduction is closely intertwined with propaganda and indoctrination. Looking at the peculiarities of the OL approach to indoctrination from the point of view of propaganda theory, the North Korean OL presents a good example of what Jacques Ellul $(1973,79-84)$ once described as a "horizontal propaganda." According to Ellul, "horizontal propaganda" makes use of political indoctrination within large organization networks, with a relatively small role assigned to mass media, but with special emphasis on group meetings. As Juyan Zhang and Glen Cameron demonstrate, this approach was typical for the Chinese propaganda under Mao Zedong, even though things changed in the reform eras. According to them, China's propaganda of the Mao era "is horizontal and depends on huge organisations instead of mass media. ... Before 1978, when the country started its open-door policy, such propaganda had a completely political agenda" (Zhang and Cameron 2004, 308).

In North Korea, the efficiency of group-based horizontal propaganda has been further increased by the combination of two factors. One is the previously mentioned universal reach of the OL system, which ensures that every single adult is a member of some stable group existing largely for the purposes of indoctrination. Another peculiarity is the emphasis on the active involvement of all individuals in the production of propaganda. Every member of an organization is required to 
occasionally produce properly worded utterances on political subjects. This makes every participant of the OL (that is, every adult North Korean) not only a passive recipient, but also an active manufacturer, of propaganda. This emphasis on active involvement is typical for horizontal propaganda, but in the Soviet Union, the same approach was applied largely to the members of the Communist Party and Party Youth, while in North Korea the omnipresence of the OL structure means that every adult is occasionally expected to manufacture propaganda - or at least assemble utterances in accordance with the rules of authoritative discourse.

Stepehn Kotkin (1995), when describing life in the Soviet Union in the 1930s, paid much attention to what he described as learning ways to "speak Bolshevik," to express oneself in the officially approved idiom of the system. The OL makes sure that virtually all North Koreans are trained to "speak Juche" properly-and this training has continued for decades.

Yet another important peculiarity of North Korea's OL is its intensity - the sheer amount of time a North Korean is expected to spend attending OL activities. Although the exercises have been generally less intense since Kim Il Sung's death in 1994, the OL remains very time-consuming. The average North Korean attends some OLrelated functions at least three times a week. Our interviews suggest that in an average week the OL takes about four to five hours. However, a 2002 article in a pro-Pyongyang South Korean monthly states that OL activities are even more time-consuming: "On average, OL events are conducted 4-5 days a week, taking 2-3 hours every day" (Chong 2002, 136). This might be an overstatement, even though it comes from a source that is not likely to exaggerate such things. By comparison, party activities in the Soviet Union usually took four to five hours a month.

This intensity means that every adult North Korean is exposed to the official line regularly and is made to absorb (and occasionally generate) large quantities of indoctrination material. Of course, the media also plays its role in providing North Koreans with information on how they should see the outside world and how they should behave. People can avoid newspapers (which, our informants agree, are not widely read in North Korea) or avoid listening to broadcast media, but the OL makes sure that they still spend long hours every week being exposed to what Brian Myers $(2010,18)$ describes as North Korea's Text, the body of officially approved myths and opinions. Without the OL, such a level of universal exposure would be difficult or even impossible to achieve. 
Admittedly, the non-party members are treated with some leniency. Interviewees (B-03, B-05, B-07) agree that there is a difference in the intensity of the OL among the different organizations, with OL in the KWP being the most demanding and time-consuming. The Youth Union comes second, while the three other organizations are seen as somewhat more relaxed. However, the formal schedule of events and functions does not differ much among the five organizations, and the OL clearly remains a time-consuming activity.

\section{Watching Co-workers, Watching Oneself: The Mutual Criticism Sessions}

As we mentioned earlier, the OL serves two different, if interconnected, functions. On the one hand, it delivers the requisite propaganda and ensures that all North Koreans are involved with what Roeder has described as coproduction. On the other hand, it also constitutes an important part of the surveillance system. While the ideological studies sessions are, above all, aimed at indoctrination, the surveillance and self-policing functions are largely performed during "mutual criticism sessions," which constitute the most peculiar-and, arguably, the most significant - of all OL functions.

In North Korean parlance, these sessions are officially known as saenghwal ch'onghwa, a term that can be roughly translated as "[meetings for] summing up [one's] life," but we would prefer to use the descriptive term "mutual criticism session" (MCS). During an MCS, every member of a cell is expected to publicly confess shortcomings and mistakes he or she has committed since the previous MCS (typically during the preceding week). The individual must then be criticized by another member of the same cell.

This ritual can be seen as an exercise in self-policing taken to the extreme: all members of a particular cell are required to act as a collective policeman, watching both their peers and themselves and reporting deviations in a formalized manner.

Similar events were not unknown in other communist countries. Self-criticism has always been presented as an important part of Communist Party activities, and in China the self-criticism and mutual criticism sessions, somewhat akin to those in North Korea, became quite common under Mao (for a description of Mao-era mutual criticism sessions, see Martinson 1980, 208-209; Walder 2000, 168-189; Li 2009, 64, 168-170, and especially Whyte 1974). However, in North Korea, the MCS reached a unique level of formalization and acquired features 
not found elsewhere. We agree with Sung Chull Kim (2006, 69), who wrote: "As a practice, party-life criticism [Sung Chull Kim's term for the MCS] is not unique to North Korea. . . . And yet, the practice in North Korea was distinctive in content and intensity."

The MCS began to take its current shape in the early 1960s when North Korea distanced itself from its Soviet prototypes and introduced its own version of "national Stalinism." In their well-researched article, Yi U-yong and Hwang Kyu-chin (2009) used official North Korean publications to trace the emergence of the MCS. In February 1962, Kim Il Sung suggested that regular "summations" of the members' situations and activities should be conducted by the organizations on a daily basis. Soon after, in March 1962, a plenary meeting of the KWP Central Committee approved measures aimed at increasing the party's control over KWP members. An official history of the KWP published in 1979 briefly mentions that soon after the 1962 plenary meeting, the MCS was chongsanghwa (made standard) for KWP members (Party History Institute 1979, 588). Indeed, as Yi and Hwang $(2009,131)$ discovered, on March 31, 1962, the MCS under its current name was favorably mentioned in a Rodong sinmun article-perhaps the first reference to this peculiar institution in the open North Korean media. Soon after, "transmission belts" organizations also began to introduce the system, emulating the KWP example.

It appears that, despite Kim Il Sung's 1962 suggestions, the normal frequency for the MCS at that early stage was once a month. In 1971, Kim Song-ae, Kim Il Sung's wife and then also chair of the Women's Union, casually mentioned in a speech that MCSs in the Women's Union were "conducted monthly and with due preparation" (Yi and Hwang 2009, 133).

However, the MCS system underwent a major reshuffle in the early 1970s. North Korean official sources unanimously credit Kim Jong Il with this reform. For example, in 1999, at a conference commemorating the thirty-fifth anniversary of his becoming the KWP Central Committee official, one of the presentations carried the telling title "Concerning the superiority and forcefulness of a new type of Party MCS, created by the Dear Leader Comrade Kim Jong Il."8

Indeed, Kim Jong Il, in the early 1970s, supervised (and probably initiated) a dramatic revision of the entire self-criticism system. On August 21, 1973, Kim Jong Il delivered a speech that specifically dealt with the issue and praised the experience of the arts work units (theaters, cinema studios, and the like) where relevant organizations conducted criticism sessions weekly or every second day; he also demanded that this 
new system be spread to the whole society (Yi and Hwang 2009, 136). This speech was only one of many official pronouncements and structural reforms that institutionalized the MCS as now known, and also redesigned the entire OL system. ${ }^{9}$

It seems to be a common assumption in North Korea that the MCS as such was launched by Kim Jong Il around 1970. Interviewee B-02, when asked about the origin of the MCS, replied: "Generally, it began in 1974 when Kim Jong Il was promoted to head of the Propaganda and Agitation Department [of the KWP Central Committee]. It was from that time that everybody had to attend the MCS."

Despite their importance, MCSs are seldom mentioned in the North Korean media. It is telling that neither we nor our informants could recall a single case in which the MCS was featured in a North Korean film or work of fiction. Obviously, the authorities perceive the ritual as something that should not be excessively advertised. Nonetheless, diligent MCS participation is presented-without excessive details-as a duty of every "politically conscious" North Korean. When Rodong sinmun (2004) published an article in memory of Kim Il, a late dignitary, it was his special zeal for the MCS that the editorial especially emphasized: "Merely three days before his death, Comrade Kim Il participated in an MCS, so until the last moment of his life he, as the soldier of the Party and Leader, remained an example in learning the instructions of the Great Leader [Kim Il Sung] and the teachings of the Dear Leader [Kim Jong Il]."

The MCS is normally conducted weekly, but there are some exceptions to this rule. In the agricultural cooperatives, the MCS is convened once every ten days. This frequency reflects the lifestyle of the North Korean agricultural cooperatives where the more traditional ten-day cycle is still preferred to the Western seven-day week, but it might also be connected with the perception of the farmers as a politically less important group. In contrast, in those social/professional groups that are deemed especially important or are particularly vulnerable to ideological temptations, more emphasis is placed on mutual criticism and selfcriticism and the MCSs are conducted with greater frequency. Artists, actors, and other people engaged in creative activities, for example, are required to participate in an MCS every second day (Yi and Hwang 2009, 126-127).

In addition to regular MCSs, there are monthly, quarterly, and annual MCSs. In theory, the participants focus on misdeeds committed during the previous month, quarter, or year, but in practice these sessions are not much different from the regular MCSs. 
When a self-critique is delivered during an MCS, one should start it by quoting an appropriate remark of Kim Il Sung or Kim Jong Il. When some "mistake" is admitted, its reasons are analyzed (usually lack of proper political consciousness is cited) and ways to improvement are suggested. At the end, the participant vows allegiance to the Leader and Party. Then "comradely mutual criticism" is delivered afterward. Some other member of the organization stands up and criticizes the shortcomings of the person who has just delivered the self-criticism. Normally during an MCS, every member of the organization criticizes himself or herself, criticizes a fellow member, and then receives criticism from another.

There is no need to mention too many failures, one mistake normally sufficing, so the entire self-criticism takes one to two minutes per person-and the comradely mutual criticism is even shorter. According to our interviewees (B-01, B-02, B-03, B-04, B-05), during the MCS, the cell secretary or some other appointed member of the organization takes brief notes on the content of the self-criticism and mutual criticism; these records are kept for a few years and then discarded.

At the same time, our informants uniformly agree that the regular exercises at mutual criticism and self-criticism at the MCS, despite producing considerable psychological pressure, seldom lead to the disclosure of potentially dangerous misdeeds: people are not ready to admit something that might lead to persecution and are not too eager to denounce their peers openly.

B-03's description of this make-belief nature of the MCS seems to be typical: "Women willingly admit that during the previous week they did not clean [their neighborhood area] well enough and criticize themselves for this failure. They must also say that next time they will do the job better. Alternatively, a woman criticizes herself for being late for some meeting and also promises that next time she will be on time. But one should not make confessions of, say, engaging in private trade activities, let alone commiting a more serious violation [of the official norms] than market trade. Only those transgressions that are not particularly dangerous become the subject of self-criticism."

The possible damage is also mitigated by the unofficial but widespread practice of preliminary deals struck between the MCS participants. Before the session, members quietly agree on the topics of self-criticism and mutual criticism soon to be raised, thus ensuring that the situation does not get out of control. As Helen-Louise Hunter observed when describing the MCS of the 1970s (times when, as our informants agree, the MCS was taken more seriously), "The safest thing 
to do is to be neither the most critical nor the least critical but to take the middle road" (Hunter 1999, 65).

In some cases, the MCS does not have this make-believe quality. For example, B-04 mentions that younger members of the Youth Union, who have obviously not acquired enough social experience (and also have not developed the usual cynicism), sometimes take the MCS seriously and transform this ritualistic exercise into a real confrontation. Some other interviewees also mentioned cases where the denunciations at an MCS led to serious conflicts, but they also admitted that such incidents are rare.

The self-restraint shown at these public denunciations indicates that North Koreans tend to treat the MCS as a staged performance where the virtues of political loyalty are demonstrated and simulated but not really exercised. This, however, does not mean that the system is inefficient and dysfunctional. This reminds one of the situation described by Stephen Kotkin $(1995,220)$ in his study of somewhat similar (albeit far less intense) ideological campaigns in Stalin's Soviet Union: "It was not necessary to believe. It was necessary, however, to participate as if one believed-a structure that appears to have been well understood, since what could be construed as direct, openly disloyal behavior became rare."

The MCS might be seen as a perfect embodiment of a self-policing group. The regular mutual surveillance creates lingering uncertainty about the extent to which any given individual is being monitored-and this knowledge makes an individual more reluctant to challenge the prescribed norms of social/political behavior. The MCS-based regular surveillance increases the probability that the ideological and political deviations will be discovered at an early stage, while the public confessions of the MCS remind those that are watched of the types of behavior that are considered inappropriate. This is what made the MCS into, to quote Sung Chull Kim's analysis, "the essential element . . . in the preservation of North Korea's existing party-state" (Kim 2006, 69).

\section{Conclusion}

One of the most important events in Soviet history studies (and, more broadly, the studies of "really existing socialism") was the totalitarianrevisionist debate of the 1970s and 1980s. Young historians, especially Sheila Fitzpatrick and Stephen Cohen, challenged the dominant totalitarian-model paradigm. The totalitarian model tended to portray the Soviet Union as a completely top-down entity where government control bordered on absolute, where the society was a passive subject of 
such control, and where the main mechanism of control was terror, with propaganda being a mobilizing device of secondary importance (Fitzpatrick 2007, 79). The revisionists challenged the model and suggested that terror alone could not enforce conformity and that there was some kind of social support for the regime (Fitzpatrick 2007, 80). As Fitzpatrick $(2007,89)$ said, "The urban young and the upwardly mobile identified with the Soviet project."

There is little doubt that revisionist arguments make sense-and not only in the context of Stalin's Soviet Union, but also with regard to many other societies that more or less closely followed the Soviet model. Without a significant measure of consent and support, the long-term maintenance of the system would be problematic or plainly impossible. However, this consent was often manufactured by the state, and in the case of North Korea, a number of peculiar institutions are charged with the task of persuading/controlling/disciplining the population. Many of these institutions are related to the OL, and in this article we trace how these institutions are involved in manufacturing and enforcing consent.

Among others, Brian Myers $(2010,17)$ repeatedly emphasizes that the stability of the North Korean regime testifies to a significant measure of support it enjoys domestically. Myers's recent book The Cleanest Race is, above all, a study of one of the mechanisms that make such support possible. Myers concentrates on the arguments that, if taken within the ethnonationalist frame of mind, make the regime's claims plausible and popular. However, one should look not only at the content of the official discourse, but also at the circumstances under which this discourse is produced, as well as on the ways that are used to present it to the population.

The popular support for Leninist regimes is undeniable, but it is created and reproduced under the social and cultural conditions that are maintained by the regimes. Within any society, dominant elites are capable of controlling the inflow of information and influencing the values and behavior of the majority. It has long become a truism that consent is (or might be) manufactured - not least by presenting the desirable data and denying access to the information that can challenge the worldview.

This is why the OL is so important for the continuous survival of North Korea's system. It should be seen as one of, admittedly, many ways of exposing North Koreans to the information the regime considers necessary for manufacturing the "correct" attitude to the world. The MCS, being an integral part of the OL, makes sure that these values are internalized by the North Korean populace.

The most striking feature of the OL-if compared to somewhat similar activities in other Leninist regimes-is its omnipresence. In the 
early 1970 s, when the OL was only beginning to take its current shape, Scalapino and Lee $(1972,1301)$ noted that in North Korea, "the masses are organized in greater degree and numbers than in almost any other society of the world."

Thanks to OL structures, for decades every adult North Korean has been involved in mutual surveillance, indoctrination, and coproduction activities. No other Leninist regime ever succeeded in achieving such a level of penetration-in fact, it is likely that no Leninist regime ever seriously considered such a goal, being satisfied with influencing the activist minority who were seen as future potential cadres of the bureaucracy as well as opinion leaders. This unusual totality of the system contributes to its efficiency as a regime-maintenance tool, as a way to ensure that North Koreans will make desirable conclusions from what they know-or think they know-about the world and society.

The OL itself is one of the few tools that are used to manufacture consent in North Korean society. The many policies aimed at cutting the North Koreans off from the outside world are equally important, and the more traditional print- and broadcast-based propaganda also contributes to this task. Nonetheless, OL activities have been pivotal for the regime's long-term stability and also form a unique feature of North Korean social practice.

Andrei Nikolaevich Lankov, born in Leningrad (now St. Petersburg), received his $\mathrm{PhD}$ from Leningrad State University in 1989. In 1996, he moved to Australia to take up a position at the Australian National University; in 2004, he moved back to Seoul to teach at Kookmin University, where he is now a professor. Lankov is author of numerous books dealing with North Korean history.

In-ok Kwak was born in Cholla province, South Korea. He graduated in economics from Hanyang University and worked in industry. Since 2008, he has been pursuing his PhD in the Department of North Korean Studies, Korea University, Seoul. His research focuses on the emergence of markets in North Korea after 1990.

Choong-Bin Cho is professor in the Department of Politics and Diplomacy at Kookmin University, Seoul. He received his MA from Seoul National University and $\mathrm{PhD}$ from the University of Illinois at Urbana-Champaign. His research areas are the methodology of political science, social psychology, and cross-cultural studies.

\section{Notes}

This work was supported by a grant from the National Research Foundation of Korea funded by the Korean government (NRF-2010-330-B00187).

1. In the present article, we follow North Korean documents that refer to "Western age"- that is, the number of years that have passed since an individual's birth (the East Asian concept of age is different). 
2. Even minor details and exceptions (such as the requirement for a Youth League member to present a recommendation from his or her Youth League Committee) are similar to the Soviet prototype. For the full English translation of the KWP Statute, see Simons and White (1984).

3. For statistics on the party membership, see Hanley $(2003,1075)$. World Bank official data were used to calculate the ratio (see http://data.worldbank .org/indicator/SP.POP.TOTL).

4. Stalin was obviously fond of this "transmission belts" metaphor and used it a number of times, sometimes elaborating on reasons why trade unions, women's groups, and other similar "mass organizations" should be seen as the Communist Party's transmission belts. The first use of the expression can apparently be traced to a report he delivered in 1923 (Stalin 1947, 197-203).

5. For example, in November 2005, Rodong sinmun, the major official newspaper of North Korea, published an editorial dealing with the role of trade unions in which it was stated: "Under the guidance of the Great Leader, trade unions strengthened and developed into a school of mass education, into a transmission belt of the Korean Workers Party" (Rodong sinmun 2005; italics added). A similar statement about trade unions appeared in the newspaper on December 31, 2011 (Rodong sinmun 2011 ).

6. In one of the most widely acclaimed works of the official arts-the revolutionary opera Story of a Nurse-the mortally wounded heroine spends the last minutes of her life lamenting the fact that she will never see General Kim Il Sung in person, and also worrying that her last KWP membership fees might not be delivered on time. References to the "last party membership fees" recorded on "blood-stained party cards" are common clichés in North Korean official culture; see, for example, an epic poem published in the Rodong sinmun in 2004 ( $\operatorname{Sin} 2004)$.

7. Songs - or, rather, songs' lyrics — constitute an important part of the indoctrination system, and North Koreans are required to learn new songs that are seen as politically important.

8. KCNA report, June 11, 1999.

9. These reforms were described in some detail by Sung Chull Kim (Kim 2006, 65-68).

\section{References}

Belova, Eugenia, and Valery Lazarev. 2007. "Why Party and How Much? The Soviet State and the Party Finance." Public Choice 130: 437-456.

Ch'oe, Chin-i. 2005. "Ch'ongnyon puncho setae-ui pulhaenghaesston ch'onyotul" [The unlucky girls of the youth detachments generation]. DailyNK, April 17.

Chong, Yong-ch'ol. 2002. "Chochik saenghwal yuchi-ui kunkan, saenghwal ch'onghwa" [Mutual criticism session, the basics of the OL]. Minchok 21, November.

Ellul, Jacques. 1973. Propaganda: The Formation of Men's Attitudes. New York: Vintage Books. 
Fitzpatrick, Sheila. 2007. "Revisionism in Soviet History." History and Theory 46 (December): 77-91.

Hanley, Eric. 2003. "A Party of Workers or a Party of Intellectuals? Recruitment into Eastern European Communist Parties, 1945-1988." Social Forces 81, 4: 1073-1105.

Hunter, Helen-Louise. 1999. Kim Il-song's North Korea. Westport, CT: Praeger. Kim, Sung Chull. 2006. North Korea Under Kim Jong Il: From Consolidation to Systemic Dissonance. Albany: State University of New York Press.

Konopásek, Zdenek, and Zuzana Kusá. 2006. "Political Screenings as Trials of Strength: Making the Communist Power/lessness Real." Human Studies 29, 3: 341-362.

Konrád, George, and Ivan Szelenyi. 1979. The Intellectuals on the Road to Class Power. New York: Harcourt Brace Jovanovich.

Kotkin, Stephen. 1995. Magnetic Mountain: Stalinism as a Civilization. Berkeley: University of California Press.

Li, Huaiyin. 2009. Village China Under Socialism and Reform: A MicroHistory, 1948-2008. Stanford: Stanford University Press.

Martinson, Paul. 1980. "From Reciprocity to Contradictions: Aspects of the Confucian-Maoist Transformation." In Transitions and Transformations in the History of Religions, ed. Frank E. Reynolds and Theodore M. Ludwig. Leiden: E. J. Brill.

Myers, Brian. 2010. The Cleanest Race: How North Koreans See Themselves and Why It Matters. Brooklyn, NY: Melville House.

Pak Ch'ol-min. 2007. "70 nyontae kuniptae-nun naeinsaeng-ui kippum . . . kurona songpun ap'eso" [In the 1970s, KWP admission was the happiness of my life ... however, family background comes first]. DailyNK, May 4.

Party History Institute. 1979. Choson Rotongtang ryaksa [Short history of the Korean Workers' Party]. Pyongyang: Choson Rotongtang Ch'ulp'ansa.

Rodong sinmun. 2003. "Urin-un yongwonhan sungricha" [We are eternal victors]. July 25 .

- 2004. "T'uch'olhan sinnyom-kwa sunkyolhan ryangsim-uro suryongul ongwihan ch'ungsin wonro" [A loyal old statesman who protected the Leader with clear consciousness and perfect trust]. March 9.

—. 2005. "Sonkun sitae-ui yoku-e machke chikop tongmaeng saop-ul touk kanghwahacha" [Let's strengthen even more the work of trade unions in order to meet the demands of the Army-first era!]. November 30.

- 2011. "Choson rodongdang chungang wi, tang chungang kunsa wi kongdong kuho" [Joint slogans of the KWP Central Committee and KWP Central Military Commission]. December 31.

Roeder, Philip. 1989. "Modernization and Participation in the Leninist Developmental Strategy.” American Political Science Review 83, 3: 859-884.

Scalapino, Robert, and Chong-sik Lee. 1972. Communism in Korea. Berkeley: University of California Press.

Sejong Institute. 2004. Choson Notongtang-ui oekwak tanch'e [The external organizations of the Korean Workers' Party]. Seoul: Hanulak'atemi.

Shoemaker, Merle. 1990. The Soviet Union and Eastern Europe, 20th Edition, 1989. Washington, DC: Stryker-Post Publications. 
Simons, William, and Stephen White, eds. 1984. The Party Statutes of the Communist World. The Hague: Martinus Nijhoff.

Sin, Pyon-kang. 2004. "Changkunnim ttara sungri-ui hankil" [Following the general is the sole path to victory]. Rodong sinmun, July 1 .

Stalin, Iosif. 1947. "Organizatsionnyi otchiot Tsentralnogo Komiteta RKPb XII siezdu RKPb" [The RKPb Central Committee report to the twelfth $\mathrm{RKPb}$ congress]. In Sochinenia [Works], vol. 5. Moscow: OGIZ.

Stoica, Catalin Augustin. 2005. "Once Upon a Time There Was a Big Party: The Social Bases of the Romanian Communist Party." East European Politics and Societies 19, 4: 686-716.

Walder, Andrew. 1995. "Career Mobility and the Communist Political Order." American Sociological Review 60, 3: 309-328.

2000. "When States Unravel: How China's Cadres Shaped the Cultural Revolution Politics." In State Capacity in East Asia: Japan, Taiwan, China and Vietnam, ed. K. Brødsgaard and S. Young. Oxford: Oxford University Press.

Whyte, Martin King. 1974. Small Groups and Political Rituals in China. Berkeley: University of California Press.

Yang, Mayfair Mei-hui. 1994. Gifts, Favors, and Banquets: The Art of Social Relationships in China. Ithaca: Cornell University Press.

Yi, Mu-ch'ol. 2003. "T'alpuk chaka malhanun pukhan sahoe" [North Korean society as described by North Korean writer-refugees]. In Hankuk Pangsong hakhoe [Conference of the Korean Society for Research of Broadcasts]. Seoul, December.

Yi U-yong and Hwang Kyu-chin. 2009. "Pukhan-ui saenghwal ch'onghwa hyongsong kwachong yonku" [A study of the formation of the MCS in North Korea]. Pukhan yonku hakhoepo 12, 1.

Zhang, Juyan, and Glen Cameron. 2004. "The Structural Transformation of China's Propaganda: An Ellulian Perspective.” Journal of Communication Management 8, 3: 307-321. 